\title{
Pemanfaatan Limbah Bahan Tekstil Menjadi Alat Permainan Edukatif Anak Usia Dini
}

\author{
Novi Yanthi ${ }^{\varpi_{1}}$, Margaretha Sri Yuliariatiningsih ${ }^{2}$, Nurul Hidayah ${ }^{3}$, Maya Purnama Sari ${ }^{4}$ \\ Pendidikan Guru Pendidikan Anak Usia Dini, Universitas Pendidikan Indonesia ${ }^{1}$ \\ Pedidikan Guru Sekolah Dasar, Universitas Pendidikan Indonesia2,3 \\ Program Studi Pendidikan Multimedia, Universitas Pendidikan Indonesia 4 \\ DOI: $\underline{10.31004 / o b s e s i . v 4 i 1.339}$
}

\begin{abstract}
Abstrak
Limbah benang di sentra industri rajut Binong Hati memiliki potensi ekonomis, di antaranya untuk dibuat alat permainan edukatif di PAUD. Kegiatan pengabdian kepada masyarakat ini bertujuan untuk mengembangkan kreativitas dan inovasi para ibu rumah tangga dalam membuat alat permainan edukatif thematic busy books. Metode yang dilaksanakan adalah kaji tindak melibatkan pelatihan dan pendampingan produksi thematic busy books. Kegiatan dilaksanakan mengikuti tahapan perencanaan, pelaksanaan, monitoring, evaluasi dan tindak lanjut. Kelompok sasaran terdiri atas enam orang ibu rumah tangga yang berdomisili di Kelurahan Binong. Hasil kegiatan menunjukkan bahwa tingkat pendidikan para ibu rumah tangga menjadi faktor utama kurangnya tingkat kreativitas dan inovasi produk thematic busy books. Selama proses pendampingan, kelompok sasaran mengalami kesulitan terutama dalam menentukan konten kegiatan dalam buku relevan dengan Kurikulum 2013 PAUD dan mendesain pola. Program pelatihan dan berkelanjutan bagi kelompok sasaran dapat memperkuat stabilitas usaha para ibu rumah tangga di bidang produksi thematic busy books di masa mendatang.
\end{abstract}

Kata Kunci: kreativitas dan inovasi;ape; thematic busy books;kurikulum 2013 paud

\begin{abstract}
Yarn waste in the Binong Hati knitting industry center has economic potential, including to make an educational game tool in ECE. This community service activity aims to develop the creativity and innovation of housewives in making educational tools for thematic busy books. The method used is the action review involving training and assistance in the production of thematic busy books. Activities carried out following the stages of planning, implementation, monitoring, evaluation and follow-up. The target group consisted of six housewives who live in Binong Village. The results of the activity show that the education level of housewives is a major factor in the lack of creativity and innovation in thematic busy books. During the mentoring process, the target group experienced difficulties especially in determining the content of activities in the book relevant to the Curriculum 2013 ECE and designing patterns. Training and ongoing programs for the target group can strengthen the stability of the business of housewives in the field of thematic busy books production in the future.
\end{abstract}

Keywords: creativity and innovation; ape; thematic busy books; 2013 paud curriculum.

Copyright (c) 2020 Novi Yanthi, Margaretha Sri Y, Nurul Hidayah, Maya Purnama Sari

$\triangle$ Corresponding author:

Email Address : novi.yanthi@upi.edu (Cibiru Jawa Barat, Indonesia)

Received 6 December 2019, Accepted 16 March 2020, Published 23 April 2020 


\section{PENDAHULUAN}

Sentra Industri Rajut Binong di daerah Jl. Binong Jati, Kelurahan Binong, Kecamatan Batununggal Kota Bandung, yang dirintis sejak tahun 1965 telah menjadi salah satu pusat kegiatan ekonomi yang mampu menyediakan lapangan pekerjaan bagi \pm 2.143 warga masyarakat setempat maupun pendatang. Hingga tahun 2015, masih ada sekitar 120 pelaku industri rumahan produk rajutan di daerah ini (Darusman \& Rostiana, 2018). Daya tarik kawasan ini cukup tinggi mengingat perannya sebagai salah satu pusat industri produk fashion kota Bandung. Bandung terkenal dengan pusat mode indonesia yang namanya telah terdengar hingga ke Negara tetangga Malaysia, karena di Bandung terdapat banyak butik, distro, dan industri fashion (Andriani, Rian, 2018; Darusman \& Rostiana, 2018). Untuk pangsa pasar dalam negeri, area penjualan mencapai daerah Pasar Tanah Abang, Jakarta; Pasar Klewer, Solo; Pasar Baru dan Pasar Andir, Bandung; Lampung, Bali, Cirebon, dan Batam. Jenis usaha yang dirintis secara mandiri oleh segelintir warga penduduk asli di rumah-rumah adalah produksi pakaian jadi berbahan benang rajut jenis wol. Awalnya usaha ini hanya menghasilkan pakaian untuk musim dingin seperti sweater, syal, ataupun topi menggunakan mesin rajut Brother 9 Gauge yang dioperasikan secara manual dengan tangan.

Seiring waktu, dengan perluasan home industry di daerah Binong Jati, maka di bulan April tahun 2017 lalu, Wali Kota Bandung, meresmikan daerah ini sebagai Sentra Industri Kreatif Rajut Binong (Tempo.Co, 2017) Kampung Binong Jati merupakan sentra kain rajutan atau industri rajutan, karena hampir seluruh warga kampung berprofesi sebagai perajut sejak tahun 1965 yang menjadi sumber pendapatan masyarakat di sana (Andriani, Rian, 2018; Oktaviani \& Rustandi, 2018). Bahkan di masa mendatang, kawasan ini ditargetkan sebagai daerah tujuan wisata, apalagi mengingat lokasinya yang cukup strategis relatif mudah dijangkau dengan banyak modal transportasi umum, dekat dengan pusat kota Bandung, kawasan pusat wisata atau perbelanjaan Alun-alun, Pasar Baru, dan Trans Studio Mall yang juga merupakan titik-titik lokasi yang banyak diminati oleh wisatawan baik lokal maupun mancanegara untuk dikunjungi. Pengunjung bebas memilih home industry yang akan dikunjungi mengingat banyaknya jumlah industri rumahan di daerah ini yang tersebar hampir di seluruh lingkungan RW di Kelurahan Binong, mulai dari area akses pintu masuk kawasan Jl. Binong Jati dari Jl. Gatot Soebroto maupun Jl. Ibrahim Adjie dan Jl. Hj. Basuki.

Seiring semakin berkembang pesat dan meluasnya sentra industri rajut Binong Jati ini, maka volume limbah benang yang dihasilkan juga semakin meningkat dari sisa proses produksi. Kurangnya teknologi dan sisitem manajemen pengolahan limbah padat seperti ini memang menjadi masalah yang umum ditemukan di negara berkembang seperti Indonesia dan India (Ray, 2008). Sayangnya, pemanfaatan kembali limbah tersebut menjadi produk daur ulang masih relatif rendah. Selama ini, pengolahan limbah benang tersebut biasanya hanya sebatas dikumpulkan, dijual kembali ke pengepul untuk dipintal kembali dan dijual dengan harga murah. Kalaupun didaur ulang, hanya sebatas untuk memenuhi kebutuhan pembuatan pernik aksesoris sebagai pelengkap produk sweater, cardigan, syal, topi yang berasal dari home industry di kawasan tersebut saja. Padahal, banyak alternatif pemanfaatan limbah benang, misalnya untuk pembuatan alat permainan edukatif bagi TK/PAUD.

Berjalannya tahun dan kebutuhan pasar, jumlah pelaku industri rumahan semakin bertambah dan lapangan kerja di bidang produksi pakaian rajut pun senantiasa meningkat, salah satunya melibatkan para ibu rumah tangga warga sekitar pusat industri. Jenis kegiatan usaha sampingan yang dilakukan oleh para ibu rumah tangga misalnya mengesom, memasang kancing, mengobras, melinking atau mengemas pakaian dan memeriksa kualitas produk apakah cacat atau tidak. Mengingat tingginya tingkat produksi pakaian di setiap home industry, maka jumlah ibu-ibu rumah tangga yang terlibat pun makin banyak. Hal ini terus berkembang hingga sekitar tahun 2013, untuk memenuhi kebutuhan market penjualan grosir terutama ke daerah Pasar Tanah Abang, Jakarta, sebagai salah satu pusat perkulakan grosir pakaian terbesar di Asia Tenggara. Omset mingguan yang diperoleh oleh para ibu rumah tangga yang melakukan usaha sampingan dari rumah maupun di rumah produksi 
dapat mencapai angka Rp 1.500.000,00/orang/minggu di periode puncak produksi, seperti saat bulan Ramadhan menjelang hari raya Idul Fitri atau menjelang akhir tahun.

Di lain pihak, patut disayangkan bahwa beberapa tahun belakangan ini, sebagian industri rumahan mengalami penurunan tingkat produksi yang diakibatkan persaingan bisnis dengan dibukanya industri baru di kawasan Majalaya, Kabupaten Bandung. Hal ini diperparah dengan era MEA yang memungkinkan masuknya komoditas barang serupa dari Cina yang menawarkan harga lebih murah dengan kualitas sebanding. Faktor lain datang dari rendahnya daya saing serta kreativitas produk. Aspek keterbatasan modal usaha dari para pelaku industri tersebut dan beberapa kali masa kelangkaan atau peningkatan harga bahan baku juga merupakan kontributor lain terhadap penurunan produksi. Hal terakhir yang juga turut memadamkan usaha industri rajut adalah kenaikan TDL yang telah terjadi selama kurun 3 tahun terakhir mengingat beberapa jenis mesin produksi bisa dioperasikan dengan adanya aliran listrik.

Kondisi di atas juga berimplikasi pada berkurangnya lahan mata pencaharian kelompok ibu rumah tangga yang bekerja sambilan membuat pernik aksesoris pakaian rajut melalui pemanfaatan kembali limbah benang sisa produksi karena kurangnya permintaan perajin pakaian rajut akan produk tersebut. Berdasarkan hasil wawancara diketahui bahwa harga jual aksesoris tersebut pun tergolong sangat rendah, hanya sekitar Rp 8.000,00/lusin, jauh berbeda dengan yang dipasarkan secara online. Hal ini justru makin memperparah kondisi perekonomian keluarga mereka karena sebagian besar pendapatan keluarga warga di kawasan sekitar utamanya bersumber dari usaha home industry rajutan. Dalam seminggu, rata-rata per orang hanya dapat membuat maksimal 20 lusin aksesoris bunga dengan pendapatan tertinggi $\operatorname{Rp} 160.000,00$. Itupun tidak rutin hanya jika ada permintaan dari home industry rajut.

Padahal masih ada potensi pemanfaatan limbah menjadi barang bernilai ekonomis seperti alat permainan edukatif busy books. Di era literasi sekarang, pemasaran produk sejenis cukup tinggi di luar kawasan sentra industri, apalagi dengan makin pesatnya perkembangan e-market atau e-commerce dewasa ini. Satu produk busy books di pasar online umumnya dipatok pada kisaran harga Rp 200.000,00 hingga Rp 300.000,- bergantung tingkat kompleksitas pembuatan produk. Peminat produk busy book beragam mulai dari orang tua balita atau siswa TK, sekolah, maupun mahasiswa. Sayangnya kelompok target yang terdiri dari ibu rumah tangga masih awam dengan pembuatan produk busy book ini, sehingga membutuhkan program pelatihan (workshop) secara kontinyu agar kelompok target tersebut pada akhirnya dapat terampil membuat produk yang berkualitas baik, relevan dengan kurikulum PAUD/TK, aman digunakan, dan harganya cukup terjangkau. Mengingat latar belakang masalah yang ada tersebut, maka kegiatan pengabdian ini dilaksanakan untuk meningjatkan kreativitas dan inovasi produk alat permainan edukatif thematic busy books melalui pemanfaatan limbah industri rajut Binong Jati.

Industri kreatif merupakan salah satu jenis industri yang dikembangkan dengan perhatian khusus di kota Bandung, utamanya pada masa pemerintahan Walikota Dada Rosada dan Ridwan Kamil. Definisi industri kreatif berdasarkan Departemen Perdagangan Republik Indonesia tahun 2007 dan Perda Kota Bandung Nomor 18 tahun 2011 tentang Rencana Tata Ruang Wilayah (RTRW) Kota Bandung adalah industri yang berasal dari pemanfaatan kreativitas, keterampilan serta bakat individu untuk menciptakan kesejahteraan serta lapangan pekerjaan melalui penciptaan dan pemanfaatan daya kreasi dan daya cipta individu tersebut. Penataan industri kreatif sebagai salah satu fondasi ekonomi Kota Bandung juga tertera dalam Tujuan Tata Ruang Kota Bandung yang menyatakan "mewujudkan tata ruang yang aman, nyaman, produktif, efektif, berkelanjutan, dan berwawasan lingkungan, berbasis perdagangan, jasa dan industri kreatif yang bertaraf nasional". Implementasi dari hal ini di antaranya adalah pengembangan sentra industri rumah tangga produk rajutan di daerah Binong Jati, yang diresmikan oleh Ridwan Kamil di tahun 2017 lalu. Hal ini relevan dengan Rancangan Akhir Rencana Pembangunan Jangka 
Menengah Daerah Kota Bandung 2014-2018 di mana industri kreatif fashion dan kerajinan merupakan salah satu sektor utama industri kreatif.

Menurut dokumen Rancangan Akhir Rencana Pembangunan Jangka Menengah Daerah Kota Bandung tahun 2014-2018, pertumbuhan industri ekonomi kreatif ditunjang oleh adanya sinergi mutualisme antara tiga komponen penting, yakni intelektual (akademisi), pelaku bisnis dan pihak pemerintah (Dinas KUKM dan Perindag serta Pemerintah Kota) (Eksum, tanpa tahun). Dengan dibentuknya sentra industri rajutan Binongjati, itu merupakan tanda positif bahwa pemerintah Kota Bandung memerhatikan keberlangsungan usaha industri rumah tangga tersebut. Hal ini menjadi kajian juga dalam penelitian yang dilakukan Fahmi et al., (2017) bahwa akademisi memiliki peran besar dalam pengembangan industri kreatif dan inovatif di negara berkembang seperti Indoensia.

Berdasarkan prinsip sustainability, industri kreatif sentra industri rajutan Binong jati dinilai kurang memiliki daya tahan untuk secara kontinyu melangsungkan kegiatan usahanya. Hal ini ditandai dengan semakin menurunnya jumlah pelaku usaha dan pekerja yang memiliki kegiatan ekonomi di sentra industri rajut tersebut. Jumlah pelaku usaha di tahun 2017 hanya sekitar 120 dari asalnya 400 di tahun 2011 (Darusman \& Rostiana, 2018). Sekaitan dengan konsep sustainability development sebagai amanat dalam pembangunan dunia dari PBB, industri kreatif di sentra industri rajut hanya terbatas pada produk tekstil pakaian jadi atau aksesoris pakaian semata. Hal ini mengindikasikan masih kurangnya diversifikasi jenis produk kreatif yang ada di daerah ini. Produksi diutamakan untuk memenuhi permintaan pasar sesuai tren fesyen yang sedang diminati pada periode tertentu.

Berdasarkan paparan di atas, jelas bahwa kreativitas dan inovasi produk dari pelaku usaha memegang peran penting dalam menjaga kebertahanan industri kreatif skala kecil dan menengah (Farisi, 2013; Tobing, 2016). Masih berhubungan dengan konsep industri kreatif, sentra industri rajut diyakini memiliki potensi untuk mengembangkan variasi jenis produk selain pakaian jadi dan aksesoris pakaian. Hal ini belum dilakukan oleh penggiat usaha di daerah sentra industri. Salah satu alternatif potensial dalam pembuatan alat permainan edukatif untuk digunakan di sekolah PAUD/TK berbahan baku benang rajut yang dikombinasikan dengan bahan tekstil atau kerajinan lainnya.

Lebih lanjut, terdapat penelitian yang menunjang bahwa variabel kreativitas dan inovasi memiliki pengaruh signifikan terhadap loyalitas konsumen (Tobing, 2016). Namun, variabel inovasi memiliki pengaruh yang lebih kuat terhadap loyalitas pelanggan dibandingkan dengan variable krativitas. Selanjutnya penelitian yang dilakukan oleh Irawan dan Chaharbaghi et al., (Tobing, 2016) mengungkap bahwa adaptabilitas industri terhadap tuntutan perkembangan zaman, persaingan pasar ditentukan oleh inovasi yang dilakukan pada pengembangan usaha, salah satunya pengembangan diversifikasi produk. Terkait persaingan pasar, (Mu'minah, n.d.) menyebutkan bahwa industri tekstil dan produk tekstil, salah satunya yang ada di sentra industri rajut Binong Jati tergeser oleh adanya era perdaganga bebas Cina-ASEAN (ACFTA).

Lalu apabila dilihat dari konsep green consumerism dan sustainable development, pemanfaatan limbah sentra industri rajut juga masih terbatas pada pembuatan aksesoris pakaian rajut yang pesanannya datang hanya dari lingkup sekitar sentra. Kembali mengulas paparan pada paragraf sebelumnya, limbah benang ini juga masih dapat dimanfaatkan sebagi bahan baku dalam pembuatan produk alat permainan edukatif thematic busy books. Hal ini relevan dengan hasil penelitian yang dilakukan oleh Wahyuniardi et al., (2017) yang menunjukkan hasil bahwa pelaku usaha di tujuh RW di Binong Jati memiliki kepedulian lingkungan yang sangat rendah sehingga memerlukan perbaikan sistem manajemen produksi yang lebih ramah lingkungan. Walaupun sebagian pekerja ibu rumah tangga sudah memiliki keterampilan merajut untuk membuat hiasan dekorasi rumah, tas tangan wanita, pakaian anak, bros, kalung, gelang, anting dan sebagainya, skill ini kurang dioptimalkan oleh para ibu tersebut untuk menghasilkan produk lain yang bernilai ekonomis lebih tinggi untuk dijual ke pangsa pasar yang lebih luas. Padahal pasokan bahan 
baku masih dapat dikatakan cukup melimpah dan akhirnya malah menjadi penyebab pencemaran dan penyakit bagi warga sekitar. Hal ini sejalan dengan hasil penelitian Damayanti \& Ariningsih (2016) yang mengidentifikasi adanya kelemahan pada sistem keamanan dan keselamatan para pekerja di sentra industri tersebut.

Perbaikan pada sistem produksi barang hasil dari limbah benang sisa industri rajut dapat dilakukan untuk meningkatkan kualitas dan kuantitas produk. Agar dapat dihasilkan produk berkualitas lebih baik maka kelompok target dapat menambah nilai jual produk melalui kreativitas dan inovasi desain produk serta teknik keterampilan membuat kerajinan dari bahan utama benang rajut. Selain itu, peningkatan nilai estetika produk daur ulang dapat dilakukan dengan pengembangan keterampilan membuat alat permaian edukatif busy books berbahan tekstil variatif, maksudnya dengan pemanfaatan bahan baku lain yang juga bersifat limbah atau nonlimbah seperti kain perca sisa jahitan pakaian, manik-manik, pita jepang, kain flannel, dan lain sebagainya. Hal ini relevan dengan hasil studi Fahmi et al., (2017) yang mengindikasikan bahwa kegiatan usaha ekonomi kreatif yang banyak digiatkan warga Bandung menekankan pada kemampuan kreativitas dan inovasi produk industri jasa maupun barangnya. Hal lain adalah dengan melakukan pemilahan benang limbah industri yang berkualitas baik yang kemudian dipintal ulang menggunakan mesin khusus. Hal ini terutama dilakukan untuk pembuatan produk alat permianan edukatif bagi anak usia dini yang harus aman, terbebas dari polutan zat allergen dari kandungan serat benang halus yang ada pada limbah industri rajut. Hal ini sangat penting diperhatikan mengingat salah satu syarat untuk membuat alat permainan edukatif adalah aman untuk digunakan anak usia dini (Anwar et al., 2013; Hasanah, 2019; Hayati, 2019; Hijriati, 2017; Syamsuardi, 2012).

Tak berhenti sampai di situ, kualitas produk alat permaian edukatif harus memenuhi syarat relevansi dengan tema-tema yang ada di TK/PAUD sesuai kurikulum 2013 (Rahmawati, 2014; Sulastri et al., 2017; Syamsuardi, 2012). Di samping itu, busy books yang dibuat dapat juga memiliki tema-tema yang sesuai dengan usia batita untuk menstimulasi perkembangan anak. Artinya, produk thematic busy books yang akan dipasarkan juga harus memenuhi keinginan pasar individu maupun lembaga pendidikan, dengan harga yang relatif terjangkau. Jika dibandingkan dengan yang sudah banyak beredar di pasaran, kisaran satu set busy book dibanderol pada Rp 200.000,00 sampai 300.000,00. Permintaan pasar dunia pendidikan terhadap media atau alat permainan edukatif yang dibuat dari bahan-bahan tekstil semakin meningkat dewasa ini, terutama dengan semakin banyaknya lembaga pendidikan TK/PAUD. Dalam hal ini, interaksi multilingual antara komponen akademisi (perguruan tinggi) dan kelompok pengusaha industri terjalin melalui proses perencanaan produksi.

Terkait dengan manajemen pemasaran produk, dewasa ini industri kreatif Indonesia didominasi oleh e-commerce market (Beta, 2014), seperti Tokopedia, BliBli, Lazada, dan lain sebagainya. Ada juga yang memanfaatkan laman Instagram atau Facebook. Teknik pemasaran seperti ini diyakini mampu mendongkrak angka penjualan. Kegiatan seperti yang dicanangkan oleh Gubernur Jawa Barat setiap tahun yakni Pameran produk 1000 Wirausahawan Baru. Event serupa juga diselenggarakan oleh institusi pemerintah seperti Dekranasda Provinsi, Kabupaten atau Kota, serta Dinas KUKM dan Disperindag. Hal ini juga dilakukan sebagai upaya memperkenalkan potensi sumber daya dan produk kerajinan local khas daerah Jawa Barat, khususnya sentra industri di kancah nasional dan global. Hal ini relevan dengan yang dikemukakan oleh Pasquinelli, (2010) dan Mu'minah, (n.d.) sebagai wahana untuk mengembangkan kegiatan place branding di kancah komunitas dunia. Keikutsertaan kedua kelompok mitra direncanakan secara periode, minimal setahun sekali dan diharapkan terus berkelanjutan di tahun-tahun mendatang. 


\section{METODOLOGI}

Metode yang dipilih dalam PKM ini adalah kaji tindak dengan mengimplementasikan program pelatihan (workshop) bagi kelompok ibu rumah tangga untuk meningkatkan kapasitas mereka dalam melakukan kreasi dan inovasi produk usaha berupa pembuatan alat permainan edukatif thematic busy books.

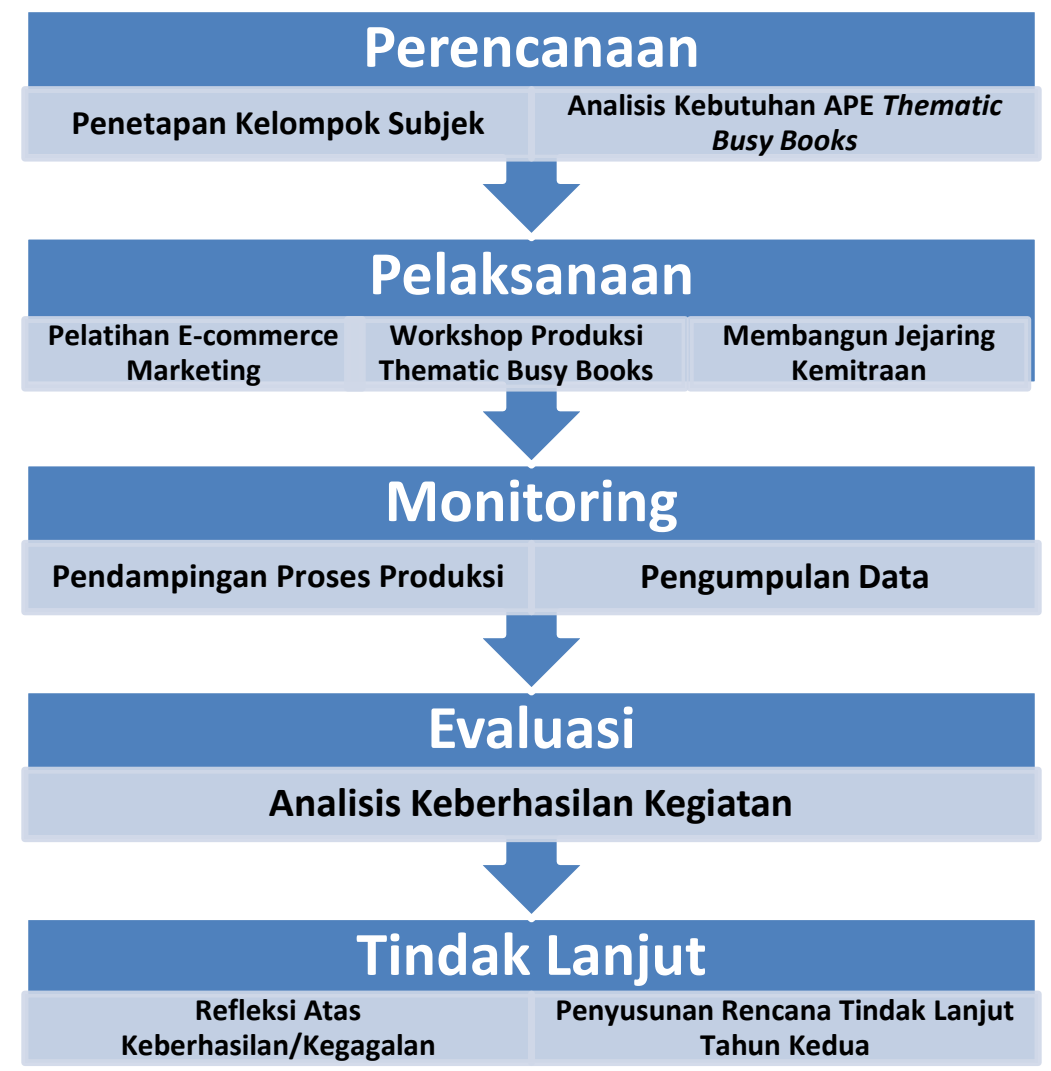

Gambar 1. Tahapan pelaksanan kegiatan

Pelatihan sendiri melibatkan dua orang mahasiswa yang sedang menyusun proposal untuk skripsi, anggota KOPMA dan seluruh mahasiswa terdaftar pada program S1 PGPAUD UPI Kampus Cibiru. Selain itu, pelatihan juga melibatkan pihak ahli di bidang tekstil dan produksi tekstil lulusan S1 STT Tekstil Bandung, juga Dosen ahli di bidang kePAUD-an.

Kelompok sasaran, dari 7 RW, dipilih kelompok ibu rumah tangga dari 3 RW yang jumlah pelaku industri rajutnya terbanyak, yakni RW 03, RW 04, RW 06. Dari ketiga RW tersebut, dipilih enam orang ibu rumah tangga yang sebelumnya atau hingga kini masih menjadi pekerja di sentra industri rajut. Kegiatan ini dilaksanakan selama 3 bulan terhitung bulan September hingga Desember 2018 di daerah sentra industri rajut Binong Jati.

\section{HASIL DAN PEMBAHASAN}

Kegiatan pengabdian yang dilaksanakan kali ini terdiri dari beberapa tahapan yang diawali dari tahap perencanaan hingga evaluasi. Adapun hingga saat ini, kegiatan yang telah rampung dilaksanakan adalah kegiatan perencanaan dan pelaksanaan hingga monitoring. Berikut dipaparkan hasil yang diperoleh pada tahapan kegiatan tersebut. 


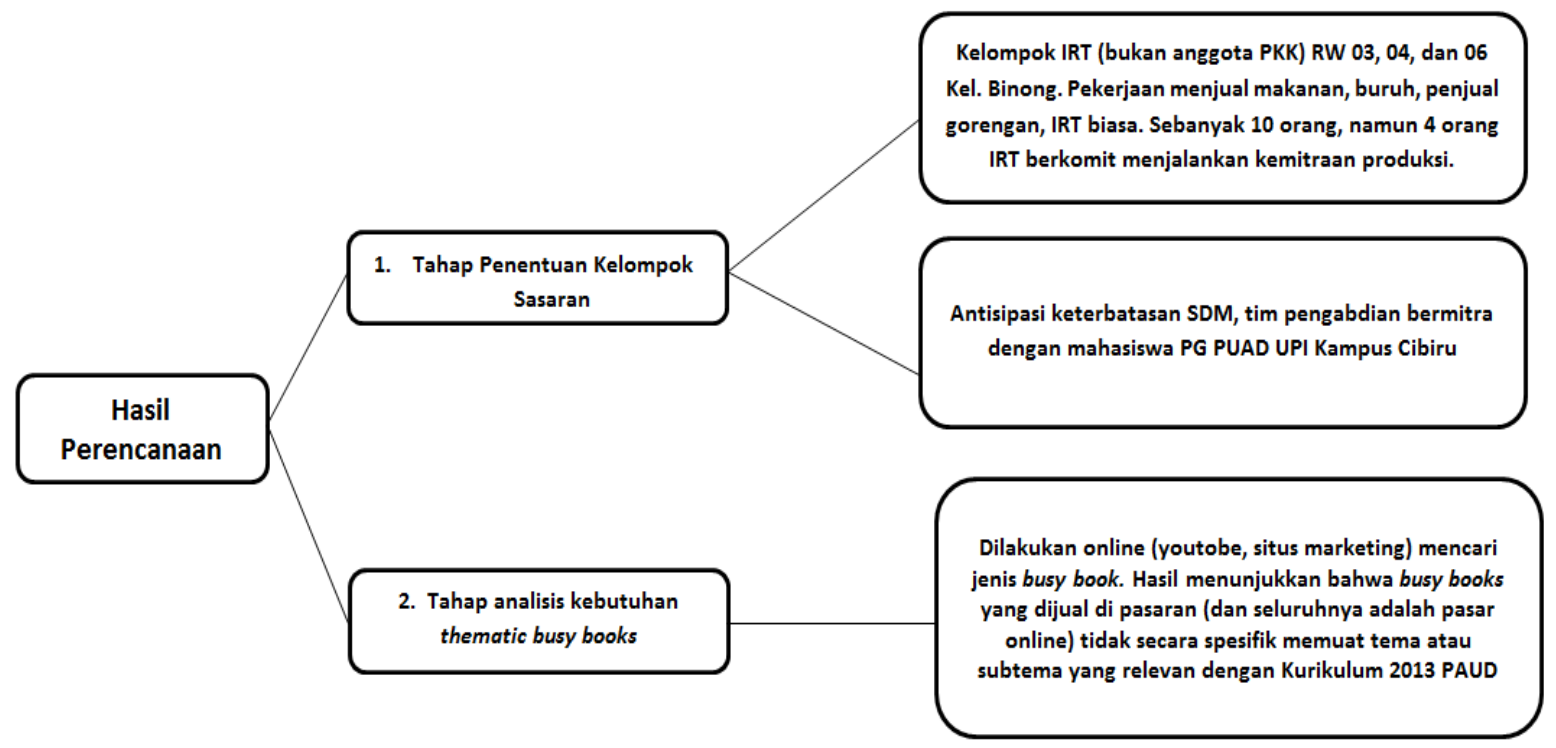

\section{Gambar 2. Hasil Tahap Perencanaan}

Pada gambar di atas merupakan tahap awal pada penelitian ini yaitu "Tahap Perencanaan". Tahap perencanaan meliputi Tahap Penentuan Kelompok Sasaran dan Tahap Analisis Kebutuhan Thematic Busy Book. Pada Tahap penentuan kelompok sasaran dilakukan penetapan kelompok subjek, atau sasaran, yaitu kelompok ibu rumah tangga (bukan anggota PKK) RW 03, 04, dan 06 Kelurahan Binong yang sehari-hari memiliki pekerjaan sampingan menjual makanan ringan, buruh pada home industry rajut Binong Jati sebagai tukang som atau mengepak barang, penjual makanan (gorengan), dan ibu rumah tangga biasa. Kelompok target sebanyak 10 orang yang direncanakan di awal, namun hingga tahap pertemuan pendampingan produksi ke 4 dilakukan, hanya 4 orang ibu rumah tangga yang berkomitmen untuk menjalankan usaha kemitraan produksi thematic busy books. Hal ini disebabkan minimnya pemahaman tentang busy book dan manfaatnya di PAUD serta keterbatasan keterampilan menjahit ibu-ibu. Akibatnya, sebagian ibu rumah tangga mundur dari kegiatan karena tidak mampu mengejar deadline dan menghasilkan busy book dengan kualitas baik yang memiliki nilai jual. Untuk mengantisipasi keterbatasan SDM, maka tim pengabdian bermitra dengan mahasiswa PGPAUD UPI Kampus Cibiru dalam kegiatan desain indikator dan konten kegiatan serta desain layout busy book. Partisipasi mahasiswa juga nampak pada saat produksi untuk membantu penyelesaian busy book.

Selanjutnya Tahap analisis kebutuhan thematic busy books, dilakukan riset online dalam channel youtube, situs marketing online seperti Lazada, Tokopedia, Blibli, Shopee, untuk mencari jenis busy book yang sudah beredar di pasaran. Hasil menunjukkan bahwa busy books yang dijual di pasaran (dan seluruhnya adalah pasar online) tidak secara spesifik memuat tema atau subtema yang relevan dengan Kurikulum 2013 PAUD. Seluruh busy books berisi konten kegiatan yang memadukan berbagai tema atau subtema, seperti Hewan, Pekerjaan, Kebutuhanku, dan lain sebagainya. Umumnya, busy books yang dijual dipesan berdasarkan pesanan khusus dan dibuat dengan manual (handmade) menggunakan material kain, benang, atau kain flanel saja. Oleh karea itu, tema kegiatan pengabdian ini untuk memproduksi busy books secara tematik sesuai yang ada pada kurikulum PAUD sangat potensial dengan pangsa pasar lebih luas, tak hanya diperuntukkan bagi pemesanan perorangan dengan konsep costum made, namun juga dapat dipasarkan ke lembaga PAUD seperti TK atau daycare, karena muatan kegiatan dalam thematic busy books yang akan dibuat disesuaikan dengan kompetensi dasar, serta Standar Pencapaian Perkembangan Anak pada kurikulum 2013 PAUD. Selain itu, inovasi dalam pembuatan thematic busy books kali ini 
menggunakan material limbah benang rajut yang masih tergolong kategori baik dan aman bagi anak usia dini, sehingga dari segi desain lebih variatif dikombinasikan dengan material kain flanel, benang sulam, kancing, dan lainnya.

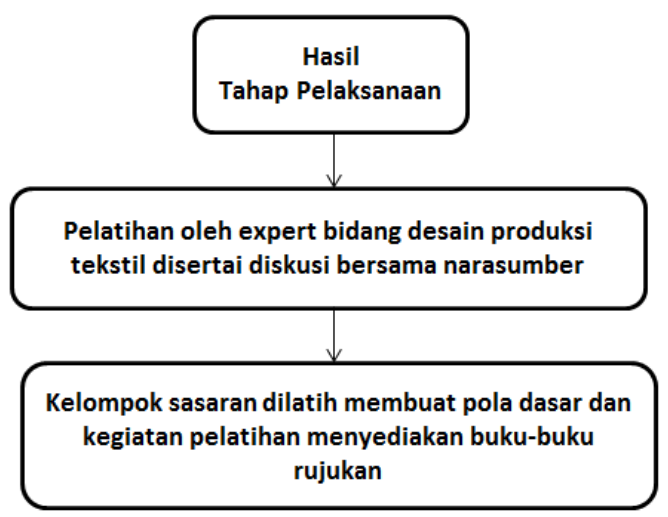

\section{Gambar 3. Hasil Tahap Pelaksanaan}

Tahap kedua pada penelitian ini adalah "Tahap pelaksanaan Workshop produksi thematic busy books". Berdasarkan gambar 3 di atas pada tahap ini, dilakukan pelatihan oleh narasumber ahli di bidang desain produksi tekstil selama 1 kali. Pelatihan diberikan terkait pengembangan ide desain konten thematic busy books. Diskusi dilakukan bersama narasumber, tim, kelompok sasaran dibantu oleh tim teknis mahasiswa PGPAUD. Kelompok sasaran juga dilatih membuat pola dasar bentuk-bentuk yang akan muncul pada konten busy books. Sekaitan dengan teknik menjahit dan merajut, pada akhirnya hanya dipilih 7 dari 10 ibu rumah tangga yang menyatakan memiliki keterampilan dasar tersebut untuk melanjutkan kegiatan pengabdian produksi thematic busy books. Kegiatan pelatihan ini juga diiringi dengan menyediakan buku-buku rujukan terkait teknik merajut dan membuat alat permainan edukatif bagi anak usia dini sebagai referensi bagi kelompok sasaran dalam proses produksi selajutnya. Hal ini diharapkan mengatasi kesulitan ibu rumah tangga sasaran dalam menentukan desain pola serta konten kegiatan yang akan muncul pada thematic busy books yang sesuai dengan muatan kurikulum PAUD.

Tahap ketiga pada penelitian ini adalah "Tahap monitoring dan evaluasi", ditemukan beberapa kendala yaitu: keterbatasan keterampilan ibu rumah tangga dalam teknik dasar menjahit dan merajut. Hal ini berpengaruh besar terhadap motivasi untuk mengikuti program kegiatan secara kontinyu dan menyelesaikan produk thematic busy book pertama sesuai tenggat waktu yang sudah dijadwalkan, yakni di Bulan Oktober. Dari 7 orang ibu rumah tangga yang awalnya menyatakan kesiapan untuk mengikuti program ini, hanya 4 orang di antaranya yang berkomitmen penuh untuk secara kontinyu melanjutkan. Karena keterbatasan sumber daya manusia pada kelompok sasaran, maka dilakukan pendampingan oleh tim mahasiswa teknis di lapangan selama proses produksi dan finishing. Narasumber ahli juga melakukan kegiatan pendampingan selama produksi. Namun, kelompok sasaran cenderung pasif dan hanya mengandalkan instruksi yang diberikan narasumber maupun hanya menanyakan dan menerima ide masukan dari mahasiswa.

Keterbatasan inovasi ide untuk menentukan konten kegiatan thematic busy book ini diasumsikan karena rendahnya tingkat pendidikan kelompok sasaran sehingga kurang mengenal apalagi memahami karakteristik dan prinsip pembuatan APE busy books sesuai muatan kurikulum 2013 PAUD. Kendala-kendala di atas berimbas pada keterlambatan proses produksi busy books tema pertama, yaitu profesi dokter. Maka hal itu diantisipasi dengan cara melibatkan lebih banyak mahasiswa dan kelompok Ibu PKK untuk membantu proses produksi buku kedua dan ketiga yang dijadwalkan harus sudah bisa bulan Desember akhir dan Januari pertengahan dan ditunjukkan pada pameran di minggu kedua bulan Desember sekaligus dipasarkan baik secara online maupun langsung. Temuan lain terkait 
kendala dalam meningkatkan inovasi dan kreativitas produk thematic busy books adalah rendahnya kapasitas ibu rumah tangga terkait hal ini seperti disampaikan pada bagian sebelumnya. Dari hasil wawancara diketahui bahwa tingkat pendidikanlah yang menjadi faktor utama penyebab hal ini.

Tahap terakhir pada penelitian ini yaitu "Tahap tindak lanjut". Hal-hal yang direfleksi adalah yaitu perlu diadakannya kegiatan layanan edukasi bagi kelompok ibu rumah tangga untuk memberikan pemahaman mengenai cara pengembangan konten busy book agar sesuai tema dan muatan kurikulum 2013 PAUD. Tentunya ini bukanlah hal yang mudah, namun dapat dilakukan seiring proses berjalan. Untuk membantu terlaksananya hal ini dengan lebih mudah, ke depannya akan dibangun kemitraan antara Prodi PGPAUD UPI kampus Cibiru, TP PKK Kelurahan Binong dengan kepengurusan yang baru, dan PAUD yang ada di sekitar kelurahan Binong untuk melibatkan guru dan orang tua siswa dalam pembuatan thematic busy books ini.

Terkait pemasaran, di kemudian hari, pemasaran akan dibantu oleh pihak prodi PGPAUD UPI kampus Cibiru dan juga KOPMA UPI Cibiru dalam mempromosikan dan penjulan langsung agar laju produksi juga semakin meningkat dan semakin membantu kesejahteraan ekonomi ibu rumah tangga juga KOPMA. Terkait merek dagang, disebabkan pengajuan paten merk dagang memerlukan tahapan proses yang panjang dengan biaya yang cukup tinggi, maka sampai saat ini belum ada kegiatan tersebut dilaksanakan. Di kemudian hari, jika stabilitas usaha pembuatan thematic busy book ini sudah dinilai baik, maka pengajuan paten merk dagang baru akan dilakukan agar keberadaan usaha kelompok sasaran lebih terjamin dan lebih diakui secara legal.

Binong Jati merupakan sentra kain rajut karena hampir seluruh warga sana berprofesi sebagai perajut dan menjadi sumber utama pendapatan (Andriani, Rian, 2018; Oktaviani \& Rustandi, 2018). Hal ini menyebabkan volume limbah benang dari produksi meningkat, sehingga limbah tersebut dapat dimanfaatkan sebagai alat permainan edukatif PAUD yang memiliki nilai ekonomis (Rahmawati, 2014). Alat permainan edukatif ini dibuat sesuai dengan usia dan pembelajaran di PAUD yaitu kurikulum 2013 yang diberi nama thematic busy book. Pembuatan alat permainan edukatif tersebut melibatkan ibu rumah tangga dengan cara memberikan pelatihan secara kontiyu. Alat permainan edukatif thematic busy book yang dibuat merupakan salah satu alternatif dalam memanfaatkan limbah industri (Hayati, 2019).

\section{SIMPULAN}

Limbah benang rajut di sentral industri Binang Jati memiliki potensi ekonomis, diantaranya adalah dapat membuat alat permainan edukatif untuk PAUD/TK. Salah satunya adalah thematic busy book. Thematic busy book dibuat sesuai dengan tema pembelajaran dikurikulum 2013 PAUD. Thematic busy book diprodukasi oleh ibu rumah tangga dengan memberikan kegiatan pengabdian kepada masyarakat untuk mengembangkan kreativitas dan inovasi ibu rumah tangga di sentra industri rajut Binang Jati.

\section{UCAPAN TERIMAKASIH}

Penulis menyampaikan rasa terima kasih kepada pihak LPPM Universitas Pendidikan Indonesia yang telah mendanai kegiatan pengabdian kepada masyarakat tahun 2019.

\section{DAFTAR PUSTAKA}

Andriani, Rian, D. (2018). Strategi Promosi UMKM Kampung Rajut Binong Jati Sebagai Kawasan Wisata Belanja. Abdimas Bsi, 1(2), 305-310. https:// doi.org/10.31294/jabdimas.v1i2.3880.g2497

Anwar, T, M., \& Ibrahim, H. (2013). Model Pengembangan Alat Permainan Edukatif Berbasis 
Sosial Budaya pada Pembelajaran Anak Didik Kelompok Bermain. Jurnal Pendidikan Dan Kebudayaan, 19(2), 236. https:/ / doi.org/10.24832/jpnk.v19i2.283

Beta, A. R. (2014). Hijabers: How young urban muslim women redefine themselves in Indonesia. International Communication Gazette, 76(4-5), 377-389. https://doi.org/10.1177/1748048514524103

Damayanti, K. A., \& Ariningsih, P. K. (2016). UKM sadar safety [Safety-aware SME].

Darusman, F. M., \& Rostiana, E. (2018). Penyerapan Tenaga Kerja pada Sentra Industri Rajutan Binong Jati Kota Bandung. Trikonomika, 22(1), 11-26. https://doi.org/10.23969/trikonomika.v14i1.588

Fahmi, F. Z., McCann, P., \& Koster, S. (2017). Creative economy policy in developing countries: The case of Indonesia. Urban Studies, 54(6), 1367-1384. https:/ / doi.org/10.1177/0042098015620529

Farisi, R. Al. (2013). Pengaruh Inovasi dan Kreativitas Pengusaha Terhadap Keberhasilan Usaha [Universitas Pendidikan Indonesia]. http://repository.upi.edu/id/eprint/154

Hasanah, U. (2019). Penggunaan Alat Permainan Edukatif (Ape) Pada Taman Kanak-Kanak Se-Kota Metro. AWLADY: Jurnal Pendidikan Anak, 5(1), 20. https://doi.org/10.24235/awlady.v5i1.3831

Hayati, Z. (2019). Penggunaan Alat Permainan Edukatif (Ape) Dari Botol Plastik Dan Koran Bekas Untuk Meningkatkan Kreatifitas Aud. AWLADY: Jurnal Pendidikan Anak, 5(1), 56. https://doi.org/10.24235/awlady.v5i1.3457

Hijriati. (2017). Peranan Dan Manfaat Ape Untuk Mendukung Kreativitas Anak Usia Dini. Bunayya: Jurnal Pendidikan Anak, III(2), 59-69. https://jurnal.arraniry.ac.id/index.php/bunayya/article/view/1699

Mu'minah, I. (n.d.). Inovasi dan Adaptability UKM Sebagai Strategi Menghadapi Persaingan ACFTA (Studi Kasus Sentra Industri Rajutan KOta Bandung). Seminar on Application and Research in Industrial Technology (SMART).

Oktaviani, F., \& Rustandi, D. (2018). Implementasi Digital Marketing dalam Membangun Brand Awareness. PRofesi Humas : Jurnal Ilmiah Ilmu Hubungan Masyarakat, 3(1), 1-20. https://doi.org/10.24198/prh.v3i1.15878

Pasquinelli, C. (2010). The limits of place branding for local development: The case of Tuscany and the Arnovalley brand. Local Economy, 25(7), 558-572. https://doi.org/10.1080/02690942.2010.532358

Rahmawati, A. (2014). Metode Bermain Peran dan Alat Permainan Edukatif untuk Meningkatkan Empati Anak Usia Dini. Jurnal Pendidikan Anak, 3(1). https://doi.org/10.21831/jpa.v3i1.2875

Ray, A. (2008). Waste management in developing Asia: Can trade and cooperation help? Journal of Environment and Development, 17(1), 3-25. https:/ / doi.org/10.1177/1070496507310742

Sulastri, Y. L., Rahma, A., \& Hakim, L. L. (2017). IbM Pembuatan Alat Permainan Edukatif (APE) Ramah Anak Bagi Guru Paud di Kota Bandung. Jurnal Pengabdian Kepada Masyarakat, 7(2), 84. https:/ / doi.org/10.30999/jpkm.v7i2.177

Syamsuardi. (2012). Penggunaan Alat Permainan Edukatif (APE) di Taman Kanak-Kanak PAUD Polewali Kecamatan Tanete Riattang Barat Kabupaten Bone. Jurnal Publikasi Pendidikan, II(1), 59-67. https:// doi.org/10.26858/ publikan.v2i1.1586

Tempo.Co. (2017). Ridwan Kamil Angkat Sentra Rajut Binong Jai Destinasi Wisata. Tempo.Co.

Tobing, F. (2016). the Effect of Knowledge Sharing and Product (Case Study: Sentra Industri Rajut Binong Jati ). Universtas Padjadjaran.

Wahyuniardi, R., Fathoni, R., Nurjaman, S., \& Gusdya, W. (2017). Monitoring dan Evaluasi IKM Tekstil dan Produk Tekstil di Kota Bandung. Jurnal Rekayasa Sistem Industri, 6(1), 1. https:// doi.org/10.26593/jrsi.v6i1.2422.1-8 